\title{
STON1 wt Allele
}

National Cancer Institute

\section{Source}

National Cancer Institute. STON1 wt Allele. NCI Thesaurus. Code C71001.

Human ST ON1 wild-type allele is located in the vicinity of 2p16.3 and is approximately 99 $\mathrm{kb}$ in length. This allele, which encodes stonin-1 protein, may be involved in the endocytic process. 